\title{
LEGAL TURBULENCE: THE COURT'S MISCONSTRUAL OF THE AIRLINE DEREGULATION ACT'S PREEMPTION CLAUSE AND THE EFFECT ON PASSENGERS' RIGHTS
}

\author{
DANIEL H. ROSENTHAL
}

\section{INTRODUCTION}

The date was January 2, 1999. A large snowstorm had slammed into Detroit that afternoon, stranding a number of Northwest Airlines airplanes on snow-covered taxiways and tarmacs. ${ }^{1}$ Many of the more than 7000 passengers returning from New Year's vacations could not deplane. ${ }^{2}$ Some waited as many as eleven hours. ${ }^{3}$ Few of the planes contained enough food and beverages for the affected passengers, and many had overflowing toilets. ${ }^{4}$ The airport closed, but Northwest continued to hope the planes would depart, despite the contrary pleas of its on-site managers. ${ }^{5}$ Even after every other airline had shut down its operations, Northwest's planes remained on the taxiways. ${ }^{6}$ When Northwest finally reversed its decision and tried to unload the passengers, it found that there were not enough accessible gates for all of the planes. ${ }^{7}$

Copyright (c) 2002 by Daniel H. Rosenthal.

1. Susan Carey, Northwest Agrees to Pay \$7.1 Million to Passengers Stranded in 1999 Blizzard, WALL ST. J., Jan. 10, 2001, at B13.

2. Id.

3. Airline to Pay \$7.1 Million for Delay, News \& ObSERVER (Raleigh, N.C.), Jan. 10, 2001, at A11 (detailing the wait time, lack of food, and overflowing toilets that Northwest passengers experienced during the snowstorm delay of January 2-3, 1999).

4. $I d$.

5. Northwest Airlines Fails to Block Suit Over 1999 Snowstorm, PR NewswIRE, Sept. 29, 2000 [hereinafter Northwest Airlines].

6. Id.

7. See Steve Twomey, On a Runway to Nowhere on a Snowy Day in Detroit, WASH. Post, Jan. 29, 1999, at A1 (describing the scene as "The Great Wait of Jan. 2 and 3"). 
The result was a traveler's worst nightmare. Imprisoned against their will, the passengers seemingly lacked basic rights. As one observer commented, the "Great Wait ... gave passengers used to living in a mobile society a dose of a little-appreciated reality: Once your flight leaves the gate, your life is not your own. The airline rules." ${ }^{\circ} \mathrm{A}$ few weeks after the incident, some passengers received free vouchers to travel on Northwest. ${ }^{9}$ For many of them, however, that was not enough. Several of the passengers brought tort complaints against the airline in state court. ${ }^{10}$ The airline responded by claiming that the Airline Deregulation $\mathrm{Act}^{11}$ preempted the state law claims since the grievances were related to its service..$^{12}$ Finally, two years later, the parties reached agreement on a $\$ 7.1$ million settlement. ${ }^{13}$ In plaintiffs' lawyer Lawrence Charfoos's words, the settlement produced a "flashing-red-light message to airline management that passengers do have rights." 14

Despite the plaintiffs' success in this egregious case, the scope of passengers' legally actionable rights remains a hotly debated topic. In early 2001, after two summers of disorder, the public's opinion of the commercial aviation industry reached an all-time low..$^{15}$ In response, Congress held a series of hearings and threatened to approve a robust passenger rights bill despite industry lobbying efforts. ${ }^{16}$ Then, on September 11, terrorists used airplanes to attack the World Trade Center and the Pentagon, and Congressional debate shifted to airport security and safety concerns. ${ }^{17}$ Congress immediately acted to indemnify

8. Id.

9. Carey, supra note 1 , at B13.

10. Id.

11. Airline Deregulation Act of 1978, Pub. L. No. 95-504, 92 Stat. 1705 (codified as amended in scattered sections of 49 U.S.C.). Although the Supreme Court refers to the Deregulation Act as the ADA, Morales v. Trans World Airlines, Inc., 504 U.S. 374, 378 (1992), I will refer to the statute as the Deregulation Act to avoid confusion with the Americans with Disabilities Act.

12. Northwest Airlines, supra note 5. All claims of passengers bound for destinations outside of United States borders initially came under Warsaw Convention auspices. Carey, supra note 1, at B13; see also infra note 47 and accompanying text.

13. Carey, supra note 1 , at B13.

14. Id.

15. See infra notes $23-52$ and accompanying text.

16. Id.

17. See, e.g., Mac Daniel, U.S. to Aid Logan Security Efforts Program to Fund Technology Upgrade, Boston GlOBE, Feb. 7, 2002, at B4 (describing the steps the federal government has taken to improve airport security); Joe Sharkey, Despite Federal Rules, the Airlines are Still 
the airline industry from civil liability for personal and property damages resulting from the violence. ${ }^{18}$ It also approved legislation to rejuvenate the crippled airline industry via a package of financial compensation and loan guarantees. ${ }^{19}$

More than six months after the horrific attacks, as airlines have altered business plans and cut flights in the race to reorganize profitably, ${ }^{20}$ passengers' lack of rights has again resurfaced as a serious problem. ${ }^{21}$ This Note addresses the appropriate scope of passenger rights from several different perspectives. Part I details how airlines increasingly victimize passengers and take advantage of a lack of incentives to remedy serious deficiencies. Part I also identifies the Deregulation Act's preemption clause as the source of airlines' defense to otherwise viable tort claims. Part II examines the body of law interpreting the Deregulation Act's preemption clause and concludes that passengers lack both state and federal remedies to most tortious conduct by airlines. In analyzing this jurisprudence, Part II argues that the Court's interpretation of the Deregulation Act is inconsistent with its preemption clause decisions rendered more recently under other statutes. Specifically, it draws parallels to the Court's decision in a recent case involving the National Traffic and Motor Vehicle Safety Act's preemption clause..$^{22}$ Finally, this Note concludes that the Court must narrow the Deregulation Act's preemptive scope and provide passengers with a remedy to actionable conduct by the airlines.

\section{THE PROBLEM}

Everyone has experienced it-that moment when the blood starts to boil, the lungs start to choke on recycled air, and movement

Finding Ways to Speed Favored Passengers to Their Flights, N.Y. TIMES, Feb. 27, 2002, at C2 (discussing the overall improvement in airport security since the September 11 attacks).

18. Air Transportation Safety and System Stabilization Act, Pub. L. No. 107-42, § 408, 115 Stat. 230, 240-41 (2001).

19. Id. § 101, 115 Stat. at 230.

20. See, e.g., Cynthia Wilson, Airlines Need Return of Business Flier, ST. LouIS PosTDisPATCH, Feb. 22, 2002, at C1 (describing how airlines are adapting to the post-September 11 travel world).

21. See, e.g., Bruce Mohl, What About When the Airlines Render You Nearly Insensible?, Boston GlOBE, Jan. 27, 2002, at M11 (discussing the problem of passenger rights, but recognizing that "in the wake of Sept. 11 ... fears about security far outweigh concerns about customer service"); Susan Stellin, Those Uncertain Air Connections, N.Y. TIMES, Feb. 10, 2002, § 5, at 4 (detailing the poor customer service that continues in post-September 11 travel).

22. Geier v. Am. Honda Motor Co., 529 U.S. 861, 867-74 (2000) (analyzing the National Traffic and Motor Vehicle Safety Act under both express and implied preemption doctrines). 
is restricted because the unpleasant individual in the next seat starts to occupy more than his fair space. Such is life on an airplane these days. Airline-passenger relations have degenerated into an atmosphere of disorganization and blame. One recent survey placed customer satisfaction with airlines on the same low level as satisfaction with trial lawyers, ahead of only satisfaction with cable television companies and commercial diet programs. ${ }^{23}$

Between 1995 and 1999, flight delays soared by a remarkable 58 percent and cancellations increased by 68 percent, according to Federal Aviation Administration (FAA) statistics. ${ }^{24}$ At the same time, total flight operations grew by a mere 8.3 percent. ${ }^{25}$ Congress reacted to rising passenger complaints in the fall of 1999. Initially, Congress chose simply to include passenger rights elements in its funding bill for the Department of Transportation (DOT) ${ }^{26}$ Hoping to fend off more expansive passenger rights legislation, the major airlines ${ }^{27}$ voluntarily agreed to submit customer service initiatives to Congress and the DOT. ${ }^{28}$ Each airline proposed a series of areas in which they would work to improve services for their customers. ${ }^{29}$

Unfortunately, none of the initiatives had any chance to produce real change. ${ }^{30}$ For instance, both United Airlines and US Airways included language in their plans promising to "provide on-time baggage delivery." ${ }^{31}$ The combination of such broad language and the lack of

23. James R. Asker, Why Are Passengers So Angry at Carriers?, AviATION WK. \& SPACE TECH., Oct. 25, 1999, at 50, 52 (citing a survey by the Consumer Union of the United States).

24. Paul Mann, Airlines Treat Patrons 'Like Cattle,' Feds Say, AviATion WK. \& SpACE TECH., Aug. 7, 2000, at 52, 52 (reporting FAA statistics that show staggering increases in the numbers of delays and cancellations, and in the length of delays).

25. $I d$.

26. See, e.g., House Backs $\$ 10.1$ Billion FAA Funding, Passenger Rights, Aviation DaiLy, Oct. 4, 1999, at 2 [hereinafter House Backs Passenger Rights] (detailing the congressional conference report on the transportation funding bill that included money to address customer service complaints).

27. This terminology is commonly used to describe United Airlines, American Airlines, Delta Air Lines, Northwest Airlines, Continental Airlines, US Airways, and America West Airlines. Trans World Airlines was a member of this group until it was purchased by American Airlines in January 2001.

28. U.S. Carriers Debut Customer Service Plans, but Congress is Skeptical, AviATION DAILY, Sept. 16, 1999, at 1.

29. Id.

30. In 1999, airlines limited the size and number of carry-on bags, charged higher penalty fees for ticket changes, and failed to provide timely information about a rising number of delays. E.g., Study Finds Airline Service in Decline, Aviation WK. \& Space TeCH., Apr. 17, 2000, at 76, 76 [hereinafter Airline Service Decline].

31. Id. 
an enforcement mechanism rendered these initiatives ineffective. ${ }^{32}$ Passenger complaints doubled again within the year. ${ }^{33}$ Flight delays continued to increase 12 percent faster in the first five months of 2000 than in the same period in $1999 .{ }^{34}$ Indeed, in the twelve months following the airlines' voluntary promises, flight delays cost business travelers 5 billion dollars and 1.5 million hours. ${ }^{35}$ This amount prompted National Business Travel Association Executive Director Marianne McInerney to conclude that "[w]e are at a point where our nation's airline system is in need of triage."

Gradually, the congressional leadership began to use sharp rhetoric when critiquing the airlines. Former House Budget Committee Chairman John Kasich called the airlines "terrible., ${ }^{37} \mathrm{He}$ added that "they're not responsive, they're monopolistic, and the customer comes last." ${ }^{38}$ Nevertheless, the airline industry was still able to thwart congressional efforts to approve regulatory passenger rights legislation. ${ }^{39}$

32. Id.; Paul Mann, Passenger Rights Movement Expected to Bounce Back, AVIATION WK. \& SPACE TeCH., Oct. 25, 1999, at 54, 54 (recognizing the complaint of Congressman John D. Dingell that little in the airlines' initiatives was enforceable in any real manner); see also Bruce D. Nordwall, Airline Service Shortfalls Detailed in IG Report, AviATION WK. \& SPACE TECH., July 3, 2000, at 31, 31 (summarizing a DOT report that concluded that "airlines have a ways to go to restore customer confidence").

33. Mann, supra note 24, at 52; see also Asker, supra note 23, at 50 (detailing the number of formal DOT complaints by angered passengers from September 1998 to August 1999).

34. Mann, supra note 24, at 52 (citing a flight delay study done by DOT Inspector General Kenneth M. Mead); see also Airline Service Decline, supra note 30, at 76 (reporting that the annual Airline Quality Rating numbers had fallen dramatically in 1999 due to a steep rise in customer complaints).

35. Paul Mann, Lawmakers Puzzle Over Passenger Rights Bill, AviATiOn WK. \& SPACE TECH., Sept. 18, 2000, at 59, 59 (detailing figures compiled by the National Business Travel Association); see also Robert W. Moorman, Summoned by Slater, Airlines Vow to Improve, AVIATION WK. \& SPACE TECH., Aug. 28, 2000, at 54, 54-55 (focusing on a summit between the DOT and the major airlines to evaluate the voluntary plans and to develop new service initiatives).

36. Mann, supra note 35 , at 59 .

37. Id. at 60 .

38. Id.

39. E.g., Airlines Give $\$ 1$ Million to Political Campaigns in First Half, Aviation Daily, Sept. 1, 1999, at 2 (describing the flurry of lobbying activity by the airline industry to deter the efforts of passenger rights advocates). Moreover, no organized consumer effort exists to call attention to problems in the aviation industry. Instead, most of the efforts are at the grassroots level. Asker, supra note 23, at 50; see also United Airlines, at http://www.united.com (last visited Mar. 31, 2002) (on file with the Duke Law Journal) (presenting a web site that collects customer complaints from United Airlines travelers). 
Recognizing that the airlines were not the only culprits responsible for passenger dissatisfaction, Congress also looked at FAA disorganization and air-traffic control problems that contributed to delays. ${ }^{40}$ For the purposes of this Note, however, the airlines themselves remain at least partially to blame because they sometimes behave in ways that would create state tort and contract law causes of action but for the existence of the Deregulation Act. The examples below highlight such potentially actionable conduct.

\section{A. Flight Delays \& Cancellations}

Every day, passengers experience flight delays or cancellations for myriad reasons. ${ }^{41}$ Some delays and cancellations may even breach the contract between the airline and the passenger. Consider the following scenario. On August 4, 2000, United Airlines's overnight flight from Washington, D.C., to Paris sat on the ground for several hours before the airline cancelled it for "mechanical reasons." ${ }^{\text {"42 }}$ However, published reports later indicated that the cancellation had nothing to do with a mechanical defect on the aircraft; United pilots had just refused to take off because former United Chairman Stephen Wolf was a passenger on the flight. ${ }^{43}$ This action was clearly not one of the specified instances in which the United Airlines carrier contract permitted United to refuse to transport a passenger that had bought a

40. E.g., Laurence Zuckerman \& Matthew L. Wald, Crisis for Air Traffic System: More Passengers, More Delays, N.Y. TIMES, Sept. 5, 2000, at A1 (outlining the different entities responsible for airline delays and cancellations not related to acts of God, including the airlines, the FAA, and the nation's air traffic control system).

41. When this happens, it does not help that airlines often do not divulge the reason for the delay. Under their nonbinding customer service rules, airlines are under no obligation to inform consumers of the truthful reason behind any cancellation. Fitzgerald Calls on Airlines to 'Be Straight' with Customers About Delays and Cancellations, PR NEWswIRE July 13, 2001, at 1. While this Note does not explore specific state law claims against the aviation industry, there is sufficient evidence that the airlines have taken advantage of the preemption clause's protections from liability.

Another customer service problem regularly occurs when airline representatives do not provide customers with truthful communications and updates. Mann, supra note 24, at 52 (reporting the comments of Senator Frank Lautenberg that, “"[a]t a minimum, [passengers] don't want to be lied to [by the airlines]"'). To help alleviate this concern, most potential versions of passenger rights bills would require airlines to be truthful in their communications with passengers. Mann, supra note 35, at 59. Unfortunately, enforcement of this goal would be extremely difficult. Id. (detailing the legislative battles over passenger rights).

42. Robert W. Moorman, United Airlines' Flight Into Unfriendly Skies, AviATION WEEK \& SpACE TeCH., Aug. 14, 2000, at 42, 43 (describing the Wolf story and the impact of labor troubles on flight schedules).

43. Id. 
ticket. ${ }^{44}$ Yet, for reasons I explain below, hundreds of passengers were left with no viable remedy.

\section{B. Negligent Provision of Alcohol}

Imagine a bar that continues to serve alcohol to a clearly intoxicated and belligerent individual. If the drunken individual were to commit a tort, the injured party might bring suit against the bar under a negligence theory. Now picture an airplane where the flight attendant continues to serve alcohol to a group of intoxicated first-class passengers. The drunken passengers insult a fellow passenger. The victim sues the flight attendant and the airline. The court would reject her claim (again, for reasons I explain below) because the provision of alcohol is an airline "service." 45

\section{Lost Baggage \& Negligent Misrepresentation}

A honeymooning couple travels from New York City to Anguilla. En route, one of their two bags is lost. During repeated telephone calls to track down their bags, the airline's representatives repeatedly tell the couple that the airline knows the location of the bag and that it is on its way. ${ }^{46}$ This information is false, and the bags are never found. The couple sues the airline for fraud, negligent misrepresentation, negligent infliction of emotional distress, and intentional infliction of emotional distress. As shown below, they have no remedy because of the Deregulation Act. ${ }^{47}$

44. See United Airlines Conditions of Contract: Summary of Incorporated Terms $\S 5$, UAL.com, at http://www.ual.com/site/primary/0,10017,2671,00.html (Google cache file of website last visited April 30,2002) (stating that United Airlines can refuse to transport a passenger if (1) the government has requisitioned space on the flight, (2) the passenger has not complied with "government travel requirements," (3) the "passenger's conduct is disorderly/abusive or violent or passenger appears to be intoxicated under the influence of drugs or mentally deranged or engages in any action which might jeopardize [flight safety]," or (4) completing the trip would be dangerous to the passenger's mental or physical safety) (on file with the Duke Law Journal). Since the airlines have no obligation to inform passengers of the actual reason for any delay, see supra note 41 and associated text, the problem described above is made worse by the fact that passengers are dependent on the airline to inform them that the airline is acting outside the scope of its contractual authority.

45. The Ninth Circuit reached this conclusion on these facts in Harris v. American Airlines, Inc., 55 F.3d 1472, 1476 (9th Cir. 1995).

46. These are the facts of Siben v. American Airlines, Inc., 913 F. Supp. 271, 278-79 (S.D.N.Y. 1996).

47. Outside the Deregulation Act's coverage, however, these passengers still might prevail. More specifically, the plaintiffs may have a limited remedy under the Warsaw Convention because they were engaged in international travel (to Anguilla). See Convention for the Unifica- 
According to Judge Guido Calabresi's famous theory, competition in the deregulated aviation industry maximizes resource allocation and promotes good customer service on its own. ${ }^{48}$ However, rising customer frustrations ${ }^{49}$ and an increasing number of airline mergers $^{50}$ that effectively reduce the number of competitors suggest otherwise. While airline delays and customer service complaints decreased in the immediate aftermath of September 11, 2001, ${ }^{51}$ the underlying problem has resurfaced as passengers return to air travel. ${ }^{52}$

\section{THE SUPREME COURT'S EFFORTS: INCONSISTENT INTERPRETATION AND INSUFFICIENT REMEDIES}

Unfortunately, passengers probably have no contractual or tortious recourse against the airlines or their employees. Since the Deregulation Act's enactment in 1978, passengers bringing state law claims based on tort and contract law have often found their claims to

tion of Certain Rules Relating to International Transportation by Air, opened for signature Oct. 12, 1929, arts. 1, 18, 49 Stat. 3000, 3014, 3018, reprinted in 49 U.S.C. § 40105 (1994) [hereinafter Warsaw Convention] (stating that the Warsaw Convention applies to international air travel and establishing that " $\mathrm{t}$ ] he carrier shall be liable for damage sustained in event of the destruction or loss of, or of damage to, any checked baggage or any goods, if the occurrence which caused the damage so sustained took place during the transportation by air"). To succeed, however, the plaintiffs must demonstrate that the airline could have prevented the loss. See id. art. 20, at 3019 ("The Carrier shall not be liable if he proves that he and his agents have taken all necessary measures to avoid the damage or that it was impossible for him or them to take such measures."). Even if the plaintiff succeeds, the Warsaw Convention, as modified by the Montreal Agreement, limits damages to $\$ 75,000$ unless the plaintiff can establish willful misconduct by the carrier. Agreement Relating to Liability Limitations of the Warsaw Convention and Hague Protocol, May 13, 1966, reprinted in 31 Fed. Reg. 7302, 7302 (1966) [hereinafter Montreal Agreement]. Additionally, the scope of the Warsaw Convention may be quite narrow. In one case, for example, the defendant airline knowingly sprayed pesticide that made the plaintiff passenger sick, but the action was not considered an "accident." Therefore, neither the Warsaw Convention nor the Deregulation Act preempted the plaintiff's claim. Capacchione v. Qantas Airways, Ltd., 25 Av. L. Rep. (CCH) II 17,346, at 17,349 (C.D. Cal. Jan. 5, 1996).

48. Guido CAlABresi, The Cost of ACCIDENTS: A LEgAL \& ECONOMIC ANALYSIS 83 (1971).

49. E.g., Mohl, supra note 21, at M11 (quoting one customer as stating that the airlines do not hear the consumer "'at all”").

50. E.g., David Leonhardt, What Will Deal Mean? Depends on Destination, N.Y. TIMES, Jan. 10, 2001, at C1 (discussing the American buyout of Trans World Airlines in light of the proposed merger of United and US Airways).

51. E.g., Stellin, supra note $21, \S 5$, at 4 (citing a DOT report that found that, due to a decreased flight schedule, $84.7 \%$ of aircraft arrived on time in November 2001 compared to $72.8 \%$ in November 2000).

52. E.g., Mohl, supra note 21, at M11 (discussing a climate that favored passenger rights in early 2002). 
be preempted. ${ }^{53}$ Moreover, these unsuccessful plaintiffs lack any real federal remedy under the Act. In short, this broad judicial interpretation of the preemption clause is responsible for the current state of the airline-passenger relationship.

The Deregulation Act's preemption clause states: "a State... may not enact or enforce a law, regulation or other provision having the force and effect of law related to a price, route, or service of an air carrier." ${ }^{54}$ The Supreme Court has addressed the Act's preemption clause twice in the last decade, first in 1992 in Morales v. Trans World Airlines, Inc. ${ }^{55}$ and then again in 1995 in American Airlines, Inc. v. Wolens. ${ }^{56}$

\section{A. The Supreme Court's First Try}

In Morales, the Court evaluated states' attorneys general guidelines on illicit practices of the air travel industry. ${ }^{57}$ The attorneys general argued that the guidelines did not have the "force and effect" of law under the preemption clause..$^{58}$ Instead, they claimed that the guidelines merely "explain[ed] in detail how existing state laws appl[ied] to air fare advertising and frequent flyer programs." ${ }^{\text {"59 }}$ Additionally, they contended that the guidelines did not "relate to" airline routes, rates, or services. ${ }^{60}$ In an opinion written by Justice Scalia, the Court rejected both arguments. ${ }^{61}$ Eschewing the petitioners' claim

53. E.g., Charas v. Trans World Airlines, Inc., 160 F.3d 1259, 1265 (9th Cir. 1998) (noting that the Supreme Court has neglected to define a "service" as used in 49 U.S.C. $\S 1305$ (a)(1) (Supp. II 1976) (current version at 49 U.S.C. § 41713(b)(1) (1994))); Travel All Over the World, Inc. v. Kingdom of Saudi Arabia, 73 F.3d 1423, 1433 (7th Cir. 1996) (refusing to preempt a contract claim where the claim concerned a defendant's self-imposed obligation); Hodges v. Delta Airlines, Inc., 44 F.3d 334, 340 (5th Cir. 1995) (defining services broadly but not including food or beverage provision).

54. 49 U.S.C. $\$ 41713(b)(1)(1994)$.

55. 504 U.S. 374 (1992).

56. 513 U.S. 219 (1995)

57. Morales, 504 U.S. at 379. The petitioner Morales was Texas State Attorney General Dan Morales. He represented the National Association of Attorneys General. Id. at 375.

58. Id. at 379; see also Matthew J. Kelly, Comment, Federal Preemption by the Airline Deregulation Act of 1978: How Do State Tort Claims Fare?, 49 CATH. U. L. REV. 873, 877-78 (2000) (discussing the petitioners' argument that the guidelines were merely rules detailing how the various states' laws applied to fare advertising, flight overbooking, and frequent flyer programs).

59. Morales, 504 U.S. at 379 (quoting NAT'L Ass'N OF ATtORNEYs GENERAL, Air TRAVEL INDUSTRY ENFORCEMENT GUIDELINES, Introduction (1988)).

60. Id. at 383 .

61. Id.; see also Hughes Aircraft Co. v. Jacobson, 525 U.S. 432, 438 (1999) (commencing the analysis with a review of the statute's plain meaning); FMC Corp. v. Holliday, 498 U.S. 52, 
that Congress meant to preempt only a narrow class of claims, the Court relied upon the plain meaning of the words "relating to" and held that the Act preempted any state law that had a mere connection with an airline's rates, routes, or services. ${ }^{62}$

The Court next discussed an important precedent in the Court's preemption doctrine. ${ }^{63}$ In Shaw v. Delta Air Lines, Inc. ${ }^{64}$ the Supreme Court had broadly interpreted a preemption clause that included language similar to the Deregulation Act's clause..$^{65}$ Shaw concerned the federal Employee Retirement Income Security Act (ERISA), which preempts state law claims related to employee benefits. ${ }^{66}$ Although the Court did carve out some isolated exceptions in its Shaw opinion, ${ }^{67}$ it found that the "breadth of [the ERISA provision's] preemptive reach [was] apparent from [its] language. " ${ }^{68}$ Specifically, the ERISA clause preempted all state laws "insofar as they ... relate[d] to any employee benefit plan. ${ }^{\prime 69}$ In Morales, the majority opinion focused on the similar "relating to" phrase in giving great breadth to the Deregulation Act's preemption clause. ${ }^{70}$

The Morales Court also explored the petitioners' argument based on the Deregulation Act's savings clause. The savings clause originally stated: "[N]othing contained in this [Act] shall in any way abridge or alter the remedies now existing at common law or by statute, but the provisions of this [Act] are in addition to such reme-

56-57 (1990) ("Pre-emption may be either express or implied, and is compelled whether Congress' command is explicitly stated in the statute's language or implicitly contained in its structure and purpose.") (citing Shaw v. Delta Air Lines, Inc., 463 U.S. 85, 95 (1983)).

62. Morales, 504 U.S. at 383 (quoting BLACK's LAW DiCTIONARY 1158 (5th ed. 1979) (defining the phrase as "to stand in some relation; to have bearing or concern; to pertain; refer; to bring into association with or connection with")).

63. See Morales, 504 U.S. at 384 (focusing on a plain meaning interpretation instead of exploring the legislative history in any depth).

64. 463 U.S. 85 (1983).

65. Id. at 100; see also John T. Houchin, Case Note, Harris v. American Airlines: Flying Through the Turbulence of Federal Preemption and the Airline Deregulation Act, 51 U. MIAmI L. REV. 955, 962 (1997) (describing the Court's broad evaluation of the relevant language that later became an issue in the Deregulation Act preemption clause cases).

66. Shaw, 463 U.S. at 96.

67. Id. at $100-09$ (reviewing the breadth of the preemption clause and the few exceptions proffered by the legislative history).

68. Id.

69. 29 U.S.C. $\$ 1144$ (a) (1994) (emphasis added).

70. Morales v. Trans World Airlines, Inc., 504 U.S. 374, 383 (1992). 
dies." "71 The Court minimized the savings clause's importance in Morales in three ways. First, the Court applied its finding that the preemption language most specifically demonstrated Congress's specific intent. ${ }^{72}$ Second, Justice Scalia examined the savings clause's role and interpreted it as simply a "relic of the pre-[Deregulation Act]/no pre-emption regime." the Court held that the preemption clause's specific language prevailed over the savings clause's general language.

Finally, the Court addressed the argument that Deregulation Act preemption of state law claims would provide undue protections to airlines. ${ }^{75}$ Here, the Court attempted to develop a standard whereby lower courts could interpret the preemption clause's applicability consistently. Relying on Shaw, the Court held that "some state actions may affect airline fares in too tenuous, remote, or peripheral a manner" to invoke Deregulation Act preemption. ${ }^{76}$

Despite this attempt to develop a standard, the Morales opinion failed to address clearly whether the preemption clause contained any limits. ${ }^{77}$ In dissent, Justice Stevens undertook an exhaustive review of the Deregulation Act's legislative history. ${ }^{78} \mathrm{He}$ initially attacked the majority's plain language interpretation and found no clear evidence that Congress had intended such a broad application of the preemp-

71. 49 U.S.C. $§ 1506$ (1976). In 1994, Congress modified this language. Codification of Certain U.S. Transportation Laws as Title 49, United States Code, Pub. L. No. 103-272, § 1(e), 108 Stat. 745, 1117 (1994). In doing so, Congress expressly clarified that it did not intend any substantive change. The revised clause simply provides that "[a] remedy under this part is in addition to any other remedies provided by law." 49 U.S.C. $\$ 40120$ (c) (1994).

72. Morales, 504 U.S. at 385.

73. Id.

74. Id. (quoting Int'l Paper Co. v. Oullette, 479 U.S. 481, 494 (1987) (“[W]e do not believe Congress intended to undermine this carefully drawn statute through a general saving clause.")).

75. Id. at 390-91 (dismissing the petitioners' concern that even general state laws on gambling and prostitution could not be applied to airlines if the Court held that the Deregulation Act preempted their claim).

76. Id. at 390 .

77. See Houchin, supra note 65, at 973 (" $\mathrm{Th}[\mathrm{e}]$ chain of claims is endless because virtually any activity that an airline is associated with can be connected to the airlines' rates, routes or services.").

78. Morales, 504 U.S. at 419 (Stevens, J., dissenting) ("Instead of carefully examining the language, structure, and history of the [Deregulation Act] .... the Court disregards established canons of statutory construction, and gives the [Deregulation Act] pre-emption provision a construction that is neither compelled by its text nor supported by its legislative history.") (citations omitted). 
tion clause..$^{79}$ More specifically, Justice Stevens concluded that Congress had never expressed an interest in preempting common law tort and contract claims by individuals. ${ }^{80} \mathrm{He}$ also noted that the conferees had not considered the House's "relating to" language as being broader than the Senate version when discussing the Deregulation Act's final terms. ${ }^{81}$

\section{B. Still No Standard: The Supreme Court Tries Again}

Three years later, the Court again examined the Deregulation Act's preemption clause. Unfortunately, the decision only served to complicate the preexisting confusion. In Wolens, the respondents sued following the airline's unilateral devaluation of their frequent flyer mileage. ${ }^{82}$ The respondents brought suit under state law on both consumer fraud and breach of contract claims. ${ }^{83}$ The airline immediately won removal of the case to federal court, where it initially prevailed on preemption grounds. $^{84}$

Here, the Court's ultimate decision did not rest completely on the preemption clause. Instead, the Court distinguished between the two claims. First, it rejected the state consumer protection action based on a Morales preemption analysis, concluding that the Deregulation Act preempted the claim since the state law related to the airline's services. ${ }^{85}$

Nevertheless, the Court allowed the contract claim to proceed. In its decision, the Court isolated the "enact or enforce any law" language in the preemption clause. ${ }^{86}$ Since the contract claim rested on obligations undertaken by the airline-and not obligations required by the state-the Court found no federal preemption. ${ }^{87}$ The airline contended that the DOT should serve as the final contract arbiter. ${ }^{88}$

\footnotetext{
79. Id. at 420 .

80. Id.

81. Id. at 425-26.

82. Am. Airlines, Inc. v. Wolens, 513 U.S. 219, 222 (1995).

83. Id. at 224-25.

84. Id. at 225 .

85. Id. at 229 .

86. Id. at 226 .

87. Id. at 234-35.

88. Id. at 230-31. This would be a disastrous remedy and the Court appropriately dismissed the possibility. The DOT has nowhere near the potential to answer customer breach of contract claims. Moreover, Congress never gave the agency that power, nor do regulations exist to guide the DOT as a potential arbiter. Sue Haverkos, Note, Crash and Burn-The Airlines' Preemption Defense Goes Down in Flames: American Airlines v. Wolens, 64 U. Cin. L. REV. 1141, 1162
} 
However, noting that the DOT lacked the resources to accomplish such a task, and detecting no congressional intent that such a federal remedy existed, the Court rejected the airline's argument. ${ }^{89}$ Commentators soon referred to the rule in this case as the "Wolens exception" to federal preemption of state law claims. ${ }^{90}$

\section{Federal PREEMPtion the WAy It SHOUld BE}

A two-part standard emerged from the Supreme Court's preemption decisions. First, under Morales, a lower court must examine the nature of the airline's conduct to determine if preemption applies, ${ }^{91}$ and a court will find preemption if the conduct that gave rise to the cause of action relates to airline rates, routes, or services. ${ }^{92}$ Second, under Wolens, a lower court must determine whether the allegedly actionable conduct constitutes state regulation or self-imposed behavior by the airline. ${ }^{93}$ This standard accords unintended power to the preemption clause and is inconsistent with other preemption clause interpretations. In response, the Court should narrow the Deregulation Act's preemptive scope to allow more state law claims.

\section{A. The Court's Interpretation is Inconsistent with the Plain Language \& Legislative History}

During the era when Congress regulated the airline industry, the Federal Aviation Act of $1958^{94}$ vested federal oversight responsibility in the Civil Aeronautics Board. ${ }^{95}$ In 1978, to remove economic restrictions that thwarted aviation industry growth, Congress crafted the

(1996) ("The [DOT] has neither the procedures to deal with this type of issue nor the ability to handle such a large quantity of suits.").

89. Wolens, 513 U.S. at 232. Indeed, the lack of a federal remedy for the aggrieved party concerned the Court. Id. ("[Congress] indicated no intention to establish, simultaneously [to the Deregulation Act], a new administrative process for DOT adjudication of private contract disputes.").

90. E.g., Haverkos, supra note 88, at 1162; Matthew Kelly, supra note 58 at 885; Kyle Volluz, Comment, The Aftermath of Morales and Wolens, 62 J. AIR L. \& COM. 1195, 1213 (1997).

91. Morales v. Trans World Airlines, Inc., 504 U.S. 374, 382 (1992).

92. Id.

93. Wolens, 513 U.S. at 233-35.

94. Pub. L. No. 85-726, 72 Stat. 731 (codified as amended at 49 U.S.C. $\S \S 40101-44310$ (1994)).

95. 49 U.S.C. $\S 41713(b)(1)$; John W. Freeman, State Regulation of Airlines and the Deregulation Act of 1978, 44 J. AIR L. \& COM. 747, 750 (1979). 
Deregulation Act. ${ }^{96}$ The legislative history describes one of the problems of an overly regulated industry:

Existing law contains no specific provision on the jurisdiction of the States and the Federal Government over airlines which provide both intrastate and interstate service. The lack of specific provisions has created uncertainties and conflicts, including situations in which carriers have been required to charge different fares for passengers traveling between two cities, depending on whether these passengers were interstate passengers whose fares are regulated by the [Civil Aeronautics Board] or intrastate passengers, whose fare is regulated by a State. ${ }^{97}$

Concerned that the states simply would re-regulate what Congress had chosen to deregulate, the final bill included a preemption clause. $^{98}$ The preemption clause's "rates" and "routes" terminology is fairly straightforward, and few Deregulation Act challenges dispute these words' application. However, the "services" language within the preemption clause has provoked judicial confusion and inconsistency."

In the Deregulation Act, Congress neither defined "services" nor specified the type of state action preempted by the clause. ${ }^{100}$ Consequently, the courts have had to interpret what Congress meant, ${ }^{101}$ but they have had difficulty with the Deregulation Act's frustratingly

96. Airline Deregulation Act of 1978, Pub. L. No. 95-504, 92 Stat. 1705 (codified as amended at 49 U.S.C. $\$ \$ 40101-44310$ (1994)); see also, e.g., Kelly, supra note 58, at 877 ("The [Deregulation Act] allowed the airline industry to enhance competition and removed perceived onerous economic restrictions placed on airlines by the [Civil Aeronautics Board].").

97. H. Rep. No. 95-1211, at 16 (1978), reprinted in 1978 U.S.C.C.A.N. 3737, 3751-52.

98. 49 U.S.C. $§ 41713$ (b)(1); see also Kelly, supra note 58, at 877-78 (noting congressional concern about state intervention).

99. See Kelly, supra note 58, at 874-75 (stating that "state law claims have survived preemption in one jurisdiction but have fallen in another"). Generally, for instance, safety-related negligence claims are not preempted by the Deregulation Act. See, e.g., Trinidad v. Am. Airlines, Inc., 932 F. Supp. 521, 526 (S.D.N.Y. 1996) (holding that a plaintiff passenger injured by extreme airline turbulence did not have his negligence claim preempted by the Deregulation Act).

100. See Kelly, supra note 58, at 874 (noting that "Congress neither defined the term 'services' for purposes of [Deregulation Act] preemption, nor enumerated the types of state law actions or claims that fall victim to preemption"); see also Freeman, supra note 95, at 766-69 (attributing Congress's silence to ignorance rather than intent).

101. The result has been different findings by different courts. Kelly, supra note 58, at 87778. For example, in Continental Airlines, Inc. v. Kiefer, 920 S.W.2d 274 (Tex. 1996), the Texas Supreme Court determined that "[c]ommon-law negligence actions to recover damages for personal injuries do not impinge in any significant way on Congress's concern [with Deregulation Act preemption]." Id. at 282. 
broad language. ${ }^{102}$ In such situations, it is important to determine whether Congress had a "clear and manifest" set of goals in enacting the statute. ${ }^{103}$

According to the Act, Congress had two basic goals. First, Congress believed that "maximum reliance on competitive market forces" $" 104$ would further "efficiency, innovation, and low prices." Second, Congress wanted to improve the "variety and quality of ... air transportation services." 106 The Court cited these objectives in Morales. ${ }^{107}$ However, instead, of exploring their meaning, it chose to interpret the preemption clause's plain language. Under this strict constructionist approach, the preemption clause preempts any state law claim that relates to-or has any "connection" to-an airline's rates, routes, or services. ${ }^{108}$

This broad interpretation remains precedent today. However, the Deregulation Act's language and legislative history do not manifest a clear congressional intent to preempt the vast majority of state law claims, including those individual, high-occurrence claims that relate to airline negligence or fraud. As the Court has done in the past, it should look to its preemption clause jurisprudence in other areas to clarify the Deregulation Act's breadth. ${ }^{109}$

\section{B. The Court Should Apply its Recent Narrowing of Preemption in Other Areas}

The Court has not issued an opinion on the Deregulation Act's preemption clause since Wolens. Yet in the seven years since the Wolens decision, the ERISA precedent relied on by the Court in both

102. The savings clause's existence also has caused courts difficulty in determining Congress's specific intent with respect to the preemption clause. See Haverkos, supra note 88, at 1146 (explaining the judicial confusion in interpreting the Deregulation Act); see also infra notes 112-127.

103. Rice v. Santa Fe Elevator Corp., 331 U.S. 218, 230 (1947) (“[W]e start with the assumption that the historic police powers of the States were not to be superseded by the Federal Act unless that was the clear and manifest purpose of Congress.").

104. 49 U.S.C. $\S 40101(a)(6)$ (1994).

105. Id. $\S 40101(\mathrm{a})(12)(\mathrm{A})$.

106. Id. $\S 40101(\mathrm{a})(12)(\mathrm{B})$.

107. Morales v. Trans World Airlines, Inc., 504 U.S. 374, 378 (1992).

108. Id. at 386 (discussing the Court's broad interpretation of the "relating to" language).

109. Consider the majority opinion in Morales, which directly applied the Court's ERISA holdings to the Deregulation Act context. See id. at 384 ("Since the relevant language of the [Deregulation Act] is identical [to ERISA], we think it appropriate to adopt the same standard here [as we did in our ERISA decision]."). 
Morales and Wolens has changed, with narrower precedent having been established in the commercial areas.

In its recent, post-Wolens, ERISA decisions, the Court increasingly has taken a more thoroughgoing approach in evaluating whether the federal statute preempts state law claims. As Justice Souter wrote for the Court in Travelers Insurance, "[w]e simply must go beyond the unhelpful [statutory] text and the frustrating difficulty of defining its key ["relate to"] term, and look instead to the objectives of the ERISA statute as a guide to the scope of the state law that Congress understood would survive." ${ }^{110}$ The result of this more extensive analysis in the ERISA area is that state laws of general applicability are not preempted where the economic effects on pension and welfare plans are secondary. ${ }^{111}$

The Court also has narrowed its preemption jurisprudence in another context. In Geier v. American Honda Motor Co.,${ }^{112}$ the petitioner, a car accident victim, sought damages against an automobile manufacturer because her car lacked a driver's side airbag. ${ }^{113}$ In response, Honda argued that the National Traffic and Motor Vehicle Safety Act of 1966 ("Safety Act") ${ }^{114}$ preempted the claim. ${ }^{115}$ Justice Breyer, writing for the majority, first examined the Safety Act's preemption clause. ${ }^{116} \mathrm{He}$ found that the provision's plain language expressly preempted state regulation of the federal domain of automo-

110. New York State Conf. of Blue Cross \& Blue Shield Plans v. Travelers Ins. Co., 514 U.S. 645, 656 (1995).

111. See, e.g., De Buono v. NYSA-ILA Med. \& Clinical Servs. Fund, 520 U.S. 806, 815 (1997) (holding that a state tax on gross receipts for patient services at diagnostic and treatment centers was not preempted by ERISA.); Cal. Div. of Labor Standards Enforcement v. Dillingham Constr., N.A., 519 U.S. 316, 334 (1997) (narrowing the breadth of the "relate to" phrase in the ERISA context); Travelers Ins., 514 U.S. at 668 (allowing a generally applicable state surcharge statute to survive ERISA preemption).

112. 529 U.S. 861, 886 (2000) (holding that a "no airbag" tort complaint was not expressly preempted by the National Traffic and Motor Vehicle Safety Act of 1966 but was impliedly preempted by other statutes).

113. Id. at 865 .

114. 15 U.S.C. $\$ 1381$ (1988).

115. Geier, 529 U.S. at 867.

116. The specific provision read as follows:

Whenever a Federal motor vehicle safety standard established under this subchapter is in effect, no State or political subdivision of a State shall have any authority either to establish, or to continue in effect, with respect to any motor vehicle or item of motor vehicle equipment any safety standard applicable to the same aspect of performance of such vehicle or item of equipment which is not identical to the Federal standard.

15 U.S.C. $§ 1392(d)$ (repealed in 1994). 
bile safety standards. ${ }^{117}$ He then considered whether to extend express preemption to common law tort actions. Initially, Justice Breyer acknowledged that a "broad reading" of the preemption clause might allow express preemption of the instant claim. ${ }^{118}$ However, he noted the existence of a savings clause, similar to that in the Deregulation Act, within the Safety Act. ${ }^{119}$ Combining the two principles, the Court found that express preemption would leave "little, if any, potential liability at common law." ${ }^{20}$ Therefore, "few, if any, state tort actions would remain for the saving[s] clause to save."

Lacking a "convincing indication" that Congress intended to preempt common law tort actions in addition to state regulations, the Court refused to expressly preempt the claim based on the Safety Act provision alone. ${ }^{122}$ Next, the Court considered the Federal Motor Vehicle Safety Standard 208 ("Safety Standard"). ${ }^{123}$ The Safety Standard expressed the DOT's position on the inclusion of seat belts, airbags, and other safety devices in manufactured automobiles. ${ }^{124}$ The Court found that the DOT intended its comprehensive plan to include a mix of passive restraint devices. ${ }^{125}$ Therefore, under federal safety standards, automobile manufacturers did not have an express duty to install a particular device, such as a driver's side airbag. ${ }^{126}$ Since the petitioner's tort claim required the finding of a duty that conflicted with the mix of devices sought by the Safety Standard, the Court found implied preemption of the claim. ${ }^{127}$

\section{Interpreting Preemption Broadly is Inconsistent with Federalism}

Where congressional statutory intent is not "clear and manifest," longstanding Supreme Court jurisprudence does not interpret a fed-

\footnotetext{
117. Geier, 529 U.S. at 869.

118. Id. at 868 .

119. Id. (citing 15 U.S.C. $\S 1397(\mathrm{k})$, which provides that "compliance with" a federal safety standard "does not exempt any person from any liability under common law").

120. Id. (internal quotations omitted).

121. Id.

122. Id. at $869-74$.

123. Id. at $874-75$.

124. Geier, 529 U.S. at $877-78$ (describing the potential safety hazards of airbags in explaining why the Safety Standard did not require automobile manufacturers to include them); U.S. DEP'T OF TRANSP., FEDERAL Motor VEHICLE SAFETY STANDARD 208 (1994).

125. Geier, 529 U.S. at $878-79$.

126. Id. at 880 .

127. Id. at 886 .
} 
eral act to supersede the laws of sovereign states. ${ }^{128}$ In preemption cases, the Court's precedent prioritizes federalism concerns. Specifically, the Court's preemption analysis "must be guided by respect for the separate spheres of governmental authority preserved in our federalist system." ${ }^{129}$ Moreover, the Court begins its analysis in such cases with a "presum[ption] that Congress did not intend to pre-empt areas of traditional state regulation.",130

In Geier, the Court held that a state law claim was preempted because it would serve as an "obstacle" to successful completion of an "important" federal objective. ${ }^{131}$ The Court referenced World War IIera precedent to emphasize the important states rights concerns:

There is not-and from the very nature of the problem there cannot be-any rigid formula or rule which can be used as a universal pattern to determine the meaning and purpose of every act of Congress.... In the final analysis, there can be no one crystal clear distinctly marked formula. Our primary function is to determine whether, under the circumstances of this particular case, [the state] law stands as an obstacle to the accomplishment and execution of the full purposes and objectives of Congress. ${ }^{132}$

This precedent casts grave doubt on the current Court's rationale for giving short shrift to states' rights in Morales and Wolens. The Deregulation Act's overarching purpose was to provide the airlines with the potential for economic growth by deregulating the industry. ${ }^{133}$ Prior to the Deregulation Act, state and federal laws governed the pricing and routing of the aviation industry. The House's intent in the preemption section, expressed in the final language, was "to make clear that no state or political subdivision may defeat the purposes of the bill by regulating interstate air transportation." 134

In the short time since the Supreme Court decided Geier, one circuit court has cited Justice Breyer's majority opinion in its evalua-

128. Cal. Div. of Labor Standards Enforcement v. Dillingham Constr., N.A., 519 U.S. 316, 325 (1997); Rice v. Santa Fe Elevator Corp., 331 U.S. 218, 230 (1947); see also Metro. Life Ins. Co. v. Massachusetts, 471 U.S. 724, 738-40 (1985) (finding that a presumption against preemption of state regulations is overcome only by specific congressional intent).

129. Alessi v. Raybestos-Manhattan, Inc., 451 U.S. 504, 522 (1981).

130. Metro. Life, 471 U.S. at 740.

131. Geier v. American Honda Motor Co., 529 U.S. 861, 881 (2000).

132. Hines v. Davidowitz, 312 U.S. 52, 67 (1941), quoted in Geier, 529 U.S. at 881.

133. See supra notes $94-97$ and accompanying text.

134. Hearings on H.R. 8813 Before the Subcomm. on Aviation of the House Comm. on Pub. Works and Transp., 95th Cong. 243 (1977). 
tion of a Deregulation Act preemption clause claim. That court, however, declined to extend Justice Breyer's opinion to the latter context. ${ }^{135}$ In reaching this preemption clause decision, the circuit court refused even to consider the Geier or ERISA decisions, ${ }^{136}$ writing that "if developments in pension law have undercut holdings in airtransportation law, it is for the Supreme Court itself to make the adjustment. Our marching orders are clear: follow decisions until the Supreme Court overrules them." 137

The Court's expansive reading of the preemption clause in Morales misunderstands the preemption clause's original purpose. In acting to deregulate the aviation industry, Congress intended to provide more flexibility for airlines to institute lower airfares and new low-cost services. ${ }^{138}$ The Act contained a preemption clause to prohibit state governments from regulating that which Congress sought to deregulate.

Given a legislative history that is at best inconclusive, the breadth of the Morales decision is surprising. ${ }^{139}$ Recall Justice Souter's language in Travelers Insurance, where, writing for the majority, he criticized the ERISA statutory text as "unhelpful" and directed the Court to delve more deeply into Congress's objective. ${ }^{140}$ The Court did not utilize this approach in Morales. Instead, it simply accepted the dictionary definition of "relate to" and applied the then-existing ERISA precedent. ${ }^{141}$

Morales and Wolens do not adhere to congressional intent. Moreover, in the last seven years, the two decisions have been isolated from similar cases interpreting other statutes' preemption

135. United Airlines, Inc. v. Mesa Airlines, Inc., 219 F.3d 605, 607-08 (7th Cir. 2000).

136. See supra notes 110-127 and accompanying text.

137. Mesa Airlines, 219 F.3d at 608 (citing State Oil Co. v. Khan, 522 U.S. 3,20 (1997)).

138. E.g., Freeman, supra note 95 , at 747.

139. Moreover, in an era where the defense of states' rights has become a hallmark of the Rehnquist Court, the Deregulation Act preemption issues have produced strange bedfellows among the Justices. In Morales v. Trans World Airlines, Inc., 504 U.S. 374 (1992), Justice Scalia authored the majority opinion, while Chief Justice Rehnquist, perhaps the greatest champion of states' rights on the Court, joined the Morales dissent written by Justice Stevens. Id. at 419 (Stevens, J., dissenting).

140. New York State Conf. of Blue Cross \& Blue Shield Plans v. Travelers Ins. Co., 514 U.S. 645, 656 (1995).

141. Justice Scalia's approach should not surprise given his preference for plain meaning and his distrust of legislative history. For a general explanation of his views, see ANTONIN SCAlia, A MATter of InTERPRETATION: FedERAl COURTS AND THE LAW: AN EsSAy 36 (1997) 
clauses. ${ }^{142}$ Given the many similarities among these cases, the Court does not need to look far to reform its Deregulation Act interpretation. The Court's holding in Geier provides an appropriate framework for clarifying the growing body of law surrounding the Deregulation Act's preemption clause. Applying Geier in the Deregulation Act context would restore both meaning to the Act's savings clause and lawmaking authority to the states. As a result, individual common law tort and contract actions would be decided differently than would direct attempts by states to regulate the airline industry.

\section{CONCLUSION}

The societal and legal turbulence described in this Note results from varying interpretations of the Deregulation Act's preemption clause. Passengers who feel victimized by airline industry acts that would constitute common law torts and breaches of contract are left with inadequate remedies. Unfortunately, the potentially actionable behavior continues because the airline industry faces no legal incentive to improve. ${ }^{143}$ Consider that on January 2, 2002, three years to the day after Northwest kept its passengers on airplanes for up to eleven hours, Delta Airlines did virtually the same thing to some of its customers during an Atlanta snowstorm. ${ }^{144}$ Referring to the airlines' general, voluntary effort to improve customer service, ${ }^{145}$ one aggrieved passenger commented that she did not sense any improvement: "“Delta's attitude was," she said, "“like, "[Expletive] you, you're on our plane."”,"146

142. To ignore the ERISA pension and welfare cases, see supra notes 110-127 and accompanying text, is irresponsible given the Court's reliance on Shaw in its Morales decision.

143. Perhaps one expert says it best: "I'm really tired of hearing [airlines place blame for delays elsewhere]. Airlines blame the FAA, and what they can't blame on the FAA they blame on God."' Asker, supra note 23, at 50 (quoting Brent Bowen, director of the University of Nebraska Aviation Institute). For one such industry perspective, see Back-Door Re-Regulation Threatens Industry, Jeanniot Says, AviATION DAILY, June 7, 2000, at 5 [hereinafter ReRegulation] (describing how passengers hold the airlines accountable even when the delay is due to air traffic control or weather problems). In Europe, plans have been discussed to penalize airlines for flight delays within their control. EC to Propose Paying Passengers for Excessive Delays, AVIATION DAILY, Mar. 29, 2000, at 5.

144. Mohl, supra note 21, at M11 (describing a ten-hour ordeal for passengers on a Delta flight from Atlanta to Boston, one of approximately twenty flights that were delayed on the ground for more than six hours).

145. See supra notes $27-36$ and accompanying text.

146. Mohl, supra note 21, at M11 (quoting Allison Gilbert-Kubiak, a passenger on the Delta flight from Atlanta to Boston). 
Although Congress intended to protect the aviation industry from state deregulation, ${ }^{147}$ there is little evidence that Congress intended to preempt common law claims that do not directly attempt to regulate the economics of the industry. The potentially actionable conduct described in this Note demonstrates the scope of the problem and illustrates that passengers lack an effective remedy. Nevertheless, the preemption clause does serve an important purpose. Complete elimination of the preemption clause would open the aviation industry up to the dangers of re-regulation. ${ }^{148}$ Therefore, the key question is where to draw the line.

Given this difficulty-combined with a worsening airlinepassenger relationship-something must change. Ideally, the Court should correct its Morales error by extending the logic of its other preemption clause cases to the Deregulation Act context. A court confronted with a Deregulation Act preemption claim should undertake a two-part inquiry, beginning with an express preemption analysis. Under this approach, any claim that expressly intends to regulate the economic workings of the aviation industry would be preempted. Claims that deal with routes or rates, or where concurrent regulation is problematic, would be preempted. This would prevent states from setting fares for interstate travel, one of Congress's main fears when it deregulated the industry.

If a court failed to find express preemption, then it would undertake an implied preemption analysis similar to the analysis in Geier. Here, a court would look to DOT and FAA standards to determine if the plaintiff's claim conflicted with federal objectives. Any conflict would require preemption of the claim. However, a claim that did not conflict with federal standards would survive preemption. This twostep process would ensure protection of the aviation industry as Congress clearly intended. Additionally, passengers would have at least

147. The legislative reaction to September 11 demonstrates that even Congress recognizes the lack of clarity in this area. Shortly after the terrorist attacks, Congress took immediate actions to indemnify every layer of the airline industry against civil liability for damages resulting from the attacks. H.R. 2926, 107th Cong. $§ 408$ (2001). In doing so, Congress formally preempted state tort claims against American Airlines and United Airlines-proprietors of the four aircraft involved in the attacks - rather than rely on an interpretation of the Deregulation Act. $I d$. This action demonstrates how a workable preemption clause could prevent claims in unforeseen, high-damage situations, while still holding airlines accountable for the low-damage torts that occur on a regular basis.

148. See Re-Regulation, supra note 143, at 5 ("The greatest threat confronting the [aviation] industry today is back-door re-regulation, according to [International Association of Travel Agents] Director General Pierre Jeanniot.”). 
some measure of recourse through common law actions. The new environment would provide airlines with the incentive to respect passenger rights without destroying the industry's viability.

The longer the Court waits to intervene, the more passenger dissatisfaction will rise. ${ }^{149}$ Over the next decade, infrastructure limitations and competitive markets that produce overcrowding of planes could exacerbate the situation. Heightened airline security and continued terrorist concerns will also not make flying any easier. As one industry expert has noted, every day at airports could " "look like the Wednesday before Thanksgiving." "150

Even defenders of the Court's expansive reading of the Deregulation Act's preemption clause would acknowledge that Congress did not intend such a result.

149. Unless and until the Court clarifies the preemption clause issue, an aggrieved passenger probably should carefully consider the type of claim he or she wishes to file. Much of the jurisprudence surrounding the Deregulation Act's preemption clause involves two types of common law claims. In a tort action, the plaintiff has a high burden to carry to escape preemption of his or her claim. Only where the link to an airline's prices, routes, or services, is extremely tenuous does the plaintiff have a chance. Conversely, under the Wolens exception, a significant number of breach of contract claims can survive preemption. E.g., Haverkos, supra note 88, at 1160 ("[I]f a common-law breach of contract claim, where the result is limited to the terms of the contract, is not preserved under the [Deregulation Act's] savings clause, it seems that no state cause of action that somehow relates to airline rates, routes, or services would survive [Deregulation Act] preemption."). However, given contract damage principles, the benefits of winning a breach of contract claim may be so insignificant as to not justify a plaintiff's time and resources.

150. Airline Service Decline, supra note 30, at 76 (quoting Dean Headley, Associate Professor of Marketing, Wichita State University School of Business, and collaborator on the Airline Quality Rating annual survey). 